\title{
Alerta de sarampo
}

\section{Measles alert}

Correspondência | Correspondence:

Secretaria de Estado da Saúde de São Paulo

Av. Dr. Arnaldo, $3511^{\circ}$ andar sala 135

01246-901 São Paulo, SP, Brasil

E-mail: agencia@saude.sp.gov.br

Texto de difusão técnico-científica da

Secretaria de Estado da Saúde de São Paulo.

\author{
Divisão de Doenças de Transmissão Respiratória, do Centro de \\ Vigilância Epidemiológica "Prof. Alexandre Vranjac", Coordena- \\ doria de Controle de Doenças, da Secretaria de Estado da Saúde \\ de São Paulo e Instituto Adolfo Lutz (Laboratório de Vírus \\ Entéricos)
}

O Plano de Erradicação do Sarampo foi adotado em toda região das Américas com objetivo comum a todos os países desde 1994. Preconiza ações para investigação de todos os casos suspeitos de sarampo e efetivação das medidas de prevenção e controle da doença.

A transmissão do vírus do sarampo foi interrompida no Brasil no ano 2000. Nos últimos cinco anos, houve 10 casos da doença, quatro deles em residentes do Estado de São Paulo e seis em pessoas que estiveram em trânsito no Estado. Todos estes casos foram relacionados à importação do vírus. Os doentes não eram vacinados e contraíram o sarampo em outros países, onde a doença continua como endêmica ou epidêmica, ou foram infectados por pessoas que haviam viajado ao exterior.

Os profissionais de saúde das redes pública e privada devem estar alertas à possibilidade de importação do vírus do sarampo no período de retorno dos participantes da Copa do Mundo de Futebol de 2006 na Alemanha, onde surtos de sarampo vêm ocorrendo desde o início deste ano, assim como em outros países da Europa.

A definição de caso suspeito de sarampo é: "Toda pessoa que apresente febre e exantema acompanhados de um ou mais dos seguintes sinais e sintomas: tosse e/ou coriza e/ou conjuntivite, independente da idade e situação vacinal".

Todo caso suspeito de sarampo deve ser notificado imediatamente à Vigilância Epidemiológica, com especial atenção às pessoas com história recente (30 dias) de viagem à Europa, ou que tiveram contato com pessoas que viajaram ao exterior, para imediata realização das medidas de prevenção e controle (vacinação de rotina, vacinação de bloqueio, busca ativa de casos, busca de faltosos, e outras), no intuito de evitar a reintrodução do vírus do sarampo no Estado.
A monitoração das doenças exantemáticas e a confirmação laboratorial de todo caso suspeito de sarampo revestem-se de suma importância, tendo em vista a situação epidemiológica atual da doença no País. Portanto, os casos suspeitos devem ser acompanhados da coleta de amostras biológicas (sangue e urina) para diagnóstico sorológico e isolamento viral, as quais devem ser enviadas ao Instituto Adolfo Lutz, laboratório de referência no Estado para o Plano de Erradicação do Sarampo.

A vacina tríplice viral SCR (contra sarampo, caxumba e rubéola) é a medida de prevenção mais eficaz contra o sarampo. No calendário nacional de vacinação de rotina, a primeira dose deve ser administrada a toda criança de um ano de idade e uma segunda dose àquelas de cinco a seis anos de idade.

A vacina SCR também é recomendada aos profissionais que atuam no setor de turismo, motoristas de táxi, funcionários de hotéis e restaurantes, que mantêm contato com viajantes internacionais, e aos que viajam ao exterior, principalmente a locais onde há circulação viral atual. Inclusive, aos profissionais de saúde, que atenderão os possíveis casos.

Todo caso suspeito de sarampo deve ser notificado às Secretarias de Saúde dos municípios e do Estado. A notificação ao órgão estadual deve ser feita pelas Diretorias Regionais de Saúde (DRIs) e pela Central de Vigilância Epidemiológica do CVE, que atende 24 horas, pelo telefone $0800-0555466$ ou pelo fax (11) 3061-8132. No âmbito federal, os casos devem ser notificados ao Ministério da Saúde, por meio da SVS/Cover - GT Exantemáticas, pelos telefones (0XX61) 3315-2755/3520, e para o Centro de Informações Estratégicas em Vigilância em Saúde (CIEVS). O telefone de plantão do CIEVS é 0800-6446645, email notifica@saude.gov.br. O EPI-SUS atende às notificações pelo telefone (0xx61) 9961-5510. 